\title{
A marine heatwave drives massive losses from the world's largest seagrass carbon stocks
}

\author{
A. Arias-Ortiz ${ }^{1 \star}{ }^{1 \star}$, O. Serrano ${ }^{12,3}$, P. Masqué ${ }^{1,2,3}$, P. S. Lavery ${ }^{2,4}$, U. Mueller ${ }^{2}$, G. A. Kendrick ${ }^{3,5}$, \\ M. Rozaimi ${ }^{2,6}$, A. Esteban' ${ }^{2}$, J. W. Fourqurean ${ }^{5,7}$, N. Marbà ${ }^{8}$, M. A. Mateo ${ }^{2,4}$, K. Murray ${ }^{9}$, M. J. Rule ${ }^{3,9}$ \\ and C. M. Duarte 8,10
}

\begin{abstract}
Seagrass ecosystems contain globally significant organic carbon (C) stocks. However, climate change and increasing frequency of extreme events threaten their preservation. Shark Bay, Western Australia, has the largest C stock reported for a seagrass ecosystem, containing up to $1.3 \%$ of the total $\mathrm{C}$ stored within the top metre of seagrass sediments worldwide. On the basis of field studies and satellite imagery, we estimate that $36 \%$ of Shark Bay's seagrass meadows were damaged following a marine heatwave in 2010/2011. Assuming that 10 to $50 \%$ of the seagrass sediment $C$ stock was exposed to oxic conditions after disturbance, between 2 and $9 \mathrm{TgCO}_{2}$ could have been released to the atmosphere during the following three years, increasing emissions from land-use change in Australia by 4-21\% per annum. With heatwaves predicted to increase with further climate warming, conservation of seagrass ecosystems is essential to avoid adverse feedbacks on the climate system.
\end{abstract}

$\mathrm{V}$ egetated coastal ecosystems, including seagrass meadows, mangroves and tidal marshes, are collectively termed 'blue carbon' ecosystems, storing globally relevant carbon stocks in their sediments and biomass ${ }^{1}$. Their organic carbon (C) sink capacity is estimated to be $0.08-0.22{\mathrm{PgC} \mathrm{yr}^{-1} \text { globally }}^{2}$, accounting for an offset of $0.6-2 \%$ of global anthropogenic $\mathrm{CO}_{2}$ emissions $\left(49 \mathrm{Pg} \mathrm{CO}_{2} \text { eq } \mathrm{yr}^{-1}\right)^{3}$. However, blue carbon ecosystems are in decline worldwide ${ }^{2}$, raising concern about a potential re-emission of their $\mathrm{C}$ stocks to the atmosphere as $\mathrm{CO}_{2} \cdot \mathrm{CO}_{2}$ emissions from loss of blue carbon ecosystems are estimated at $0.15-1.02 \mathrm{PgCO}_{2} \mathrm{yr}^{-1}$, which is equivalent to $3-19 \%$ of those from terrestrial land-use change . $^{4}$

Seagrasses are marine flowering plants that consist of 72 species growing across a wide range of habitats ${ }^{5}$. Global estimates of $\mathrm{C}$ storage in the top metre of seagrass sediments range from 4.2 to $8.4 \mathrm{PgC}^{6}$, although large spatial variability exists related to differences in biological (for example, meadow productivity and density), chemical (for example, recalcitrance of $\mathrm{C}$ ) and physical (for example, hydrodynamics and bathymetry) settings in which they occur ${ }^{7,8}$. Since the beginning of the twentieth century, seagrass meadows worldwide have declined at a median rate of $0.9 \% \mathrm{yr}^{-1}$, mostly due to human impacts such as coastal development or water quality degradation ${ }^{9}$. Climate change impacts, such as ocean warming and extreme events (for example, El Niño/Southern Oscillation), are exacerbating this trend. Marine heatwaves have led to losses of foundation seagrass species that form organic-rich sediment deposits beneath their canopies (for example, Posidonia oceanica in the Mediterranean Sea ${ }^{10}$ and Amphibolis antarctica in Western Australia ${ }^{11-13}$ ). Seagrass losses and the subsequent erosion and remineralization of their sediment C stocks are likely to continue or intensify under climate change ${ }^{9}$, especially in regions where seagrasses live close to their thermal tolerance limits ${ }^{14}$.

Shark Bay (Western Australia) (Fig. 1) contains one of the largest $\left(4,300 \mathrm{~km}^{2}\right)$ and most diverse assemblages of seagrasses worldwide ${ }^{15}$, occupying between 0.7 and $2.4 \%$ of the world seagrass area. Up to 12 seagrass species are found in Shark Bay, storing $\mathrm{C}$ in their sediments and shaping its geomorphology. The two most notable seagrass banks, the Wooramel Bank and the Faure Sill, are the result of $\sim 8,000$ yr of continuous seagrass growth ${ }^{16}$. Despite seagrasses having thrived over millennia in Shark Bay, unprecedented widespread losses occurred in the austral summer of 2010/2011 in both the above- and below-ground biomass of the dominant seagrass A. antarctica and to a minor extent Posidonia australis ${ }^{12,13}$, the two species forming large continuous beds. For more than 2 months, a marine heatwave elevated water temperatures $2-4{ }^{\circ} \mathrm{C}$ above long-term averages $^{17}$. The event was associated with unusually strong La Niña conditions during the summer months that caused an increased transfer of tropical warm waters down the coast of Western Australia. With increased rates of seawater-warming in the southeast Indian Ocean and in the continental shelf of Western Australia ${ }^{18}$, Shark Bay's seagrass meadows are at risk from further ocean warming and acute temperature extremes due to their location at the northern edge of their geographical distribution. This trend could potentially accelerate the loss of one of the largest remaining seagrass ecosystems on Earth, and result in large $\mathrm{CO}_{2}$ emissions. On the basis of data from 49 sampled sites ${ }^{19}$, satellite imagery and a published model of soil $\mathrm{C}$ loss following disturbance ${ }^{20}$, we quantify the sediment $\mathrm{C}$ stocks and accumulation rates in Shark Bay's seagrasses and estimate the total seagrass area lost after the marine heatwave. We then provide a

${ }^{1}$ Institut de Ciència i Tecnologia Ambientals and Departament de Física, Universitat Autònoma de Barcelona, Barcelona, Spain. ${ }^{2}$ School of Science \& Centre for Marine Ecosystems Research, Edith Cowan University, Joondalup, WA, Australia. ${ }^{3}$ The University of Western Australia Oceans Institute, The University of Western Australia, Crawley, WA, Australia. ${ }^{4}$ Centre of Advanced Studies of Blanes (CEAB-CSIC), Blanes, Spain. ${ }^{5}$ The School of Biological Sciences, The University of Western Australia, Crawley, WA, Australia. ${ }^{6}$ School of Environmental and Natural Resource Sciences, Faculty of Science and Technology, Universiti Kebangsaan Malaysia, UKM Bangi, Selangor, Malaysia. ${ }^{7}$ Department of Biological Sciences and Marine education and Research Center, Florida International University, Miami, FL, USA. ${ }^{8}$ Global Change Research Group, IMEDEA (CSIC-UIB) Institut Mediterrani d'Estudis Avançats, Esporles, Mallorca, Spain. ${ }^{9}$ Department of Biodiversity, Conservation and Attractions, Kensington, WA, Australia. ${ }^{10}$ Red Sea Research Center (RSRC), King Abdullah University of Science and Technology, Thuwal, Saudi Arabia. *e-mail: Ariane.arias@uab.cat 


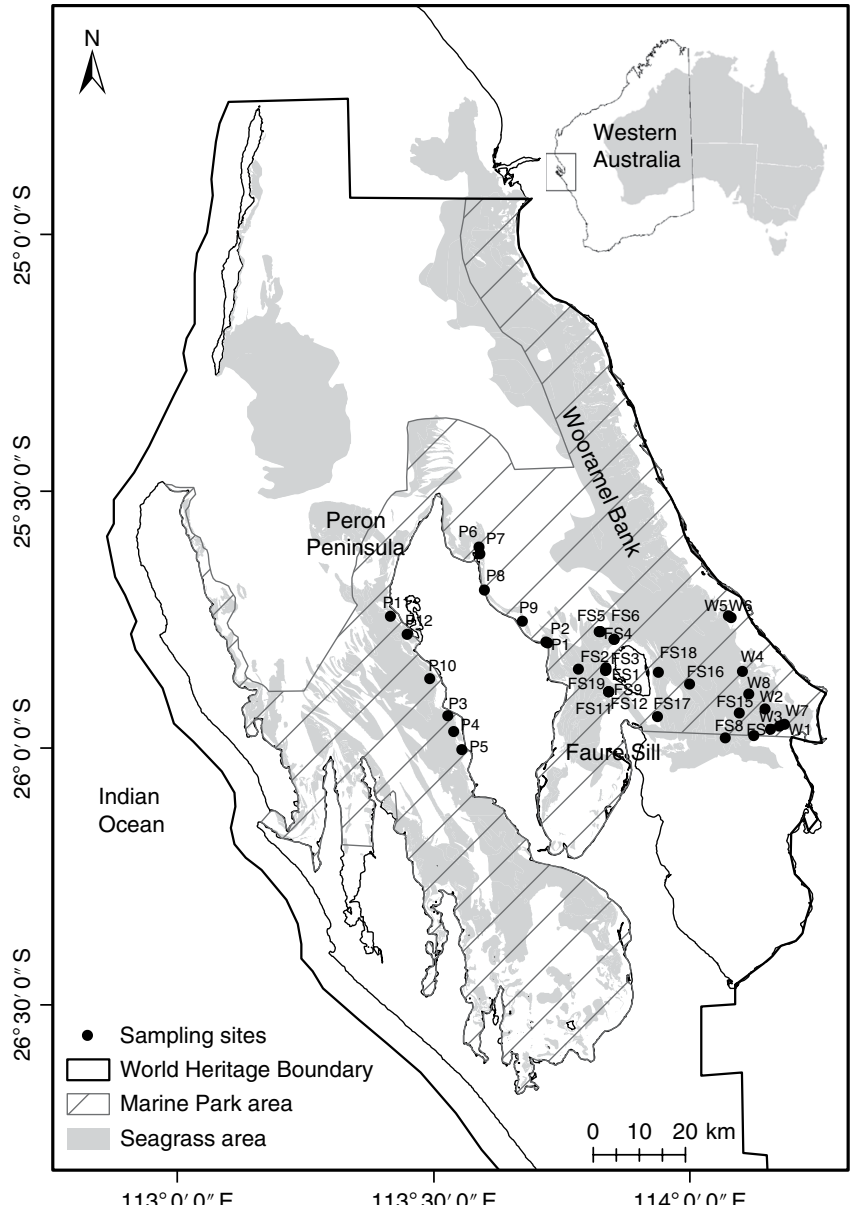

Fig. 1 | Shark Bay World Heritage Site with spatial distribution of seagrass. The two most notable seagrass banks are the Faure Sill (FS) and Wooramel $(W)$, to the west is Peron Peninsula (P). The hatched region represents Shark Bay's Marine Park and locations of individual sites within the study region are represented as solid dots. Seagrass spatial distribution, ref. ${ }^{66}$.

comprehensive assessment of the potential impact of seagrass losses on sediment $\mathrm{C}$ stocks and associated $\mathrm{CO}_{2}$ emissions in the short term ( 3 years) and long term (40 years) related to changes from anoxic to oxic conditions of previously vegetated sediments.

\section{Sediment $\mathrm{C}$ content and sources}

The C content of seagrass sediments in Shark Bay varied widely $(0.01-$ $9.00 \%)$, with the median $(1.5 \%)$ and mean \pm s.e.m. $(2.00 \pm 0.06 \%)$ values for the top metre similar to global estimates (median: $1.8 \%$ C; mean \pm s.e.m.: $2.5 \pm 0.1 \% \mathrm{C})^{6}$, although spatial variability was observed (Fig. 2). C content increased eastwards towards Shark Bay's main coastline, inversely to dry bulk density $(\rho=-0.69$; $P \leq 0.001$ ) (Supplementary Fig. 1 and Supplementary Table 1). Seagrass sediments had an average $\delta^{13} \mathrm{C}$ value $\left(\delta^{13} \mathrm{C}=\left[\left({ }^{13} \mathrm{C} /{ }^{12} \mathrm{C}\right)\right.\right.$ sample $/\left({ }^{13} \mathrm{C} /{ }^{12} \mathrm{C}\right)$ standard -1$\left.] \times 1,000\right)$ of $-13.3 \pm 0.1 \%$ o ( \pm s.e.m. $)$ throughout the entire Bay and thickness of the sampled sediment deposits. The $\delta^{13} \mathrm{C}$ signatures of potential C sources (seagrasses: $9.4 \pm 1.3 \%$, ref. ${ }^{21}$; terrestrial-derived $\mathrm{C}$ from the Wooramel River:$25.1 \%$, ref. ${ }^{22}$; seston, that is, suspended organic matter in the water column: $-19.3 \pm 2.5 \%$, ref. ${ }^{22}$ and macroalgae: $-18.1 \pm 1.8 \%$, ref. ${ }^{21}$ ) indicated that seagrasses were the main sources of sediment $\mathrm{C}$ as allochthonous matter (that is, terrestrial inputs, seston or macroalgae) could not account for the ${ }^{13} \mathrm{C}$-enriched $\mathrm{C}$ pools stored in seagrass sediments (Supplementary Table 2). Using a three-source mixing model and literature values for putative sources, the average contribution of seagrass to the entire depth of the sediment $\mathrm{C}$ stocks was estimated to be $\sim 65 \%$ (Supplementary Fig. 2), higher than the $\sim 50 \%$ estimate of seagrass contribution to surface sediments in seagrass ecosystems globally ${ }^{23}$.

The predominantly autochthonous nature of sediment $\mathrm{C}$ pools in Shark Bay seagrass meadows and the weak correlation between sediment $\mathrm{C}$ and sediment physical properties such as grain size (Supplementary Table 1) reinforce their significance for carbon sequestration. Seagrass detritus contains relatively high amounts of degradation-resistant compounds ${ }^{24}$ compared to seston and algal detritus $^{25}$, which are characterized by faster decomposition rates ${ }^{26}$. The relatively high contribution of seagrass matter throughout the 2-3-m-thick sediment deposits at Shark Bay is probably related to the low land-derived $\mathrm{C}$ inputs and the stability and high productivity of these meadows, which promote the accumulation of thick organic-rich sediments, comparable to those found in P. oceanica meadows in the Mediterranean Sea ${ }^{27}$.

\section{Seagrass C storage hotspot}

The $C$ stocks per unit area in the top metre of seagrass sediments in Shark Bay averaged $128 \pm 7 \mathrm{MgCha}^{-1}$ ( \pm s.e.m.), with $50 \%$ of the stocks having values between 92 and $161 \mathrm{MgCha}^{-1}$ (first and third quartiles, respectively) (Fig. 3a). While this is in agreement with reported median seagrass sediment $\mathrm{C}$ stock at a global scale $\left(140 \mathrm{MgCha}^{-1}\right)^{6}$, the southeastern half of Shark Bay (that is, South Wooramel Bank and Faure Sill) constitutes a hotspot of $\mathrm{C}$ storage $\left(245 \pm 6 \mathrm{Mg} \mathrm{Cha}^{-1}\right)$. Average sediment $\mathrm{C}$ stocks in 1 -m-thick deposits in Shark Bay are similar to those in temperate-tropical forests $\left(122 \mathrm{MgCha}^{-1}\right)$ and tidal marshes $\left(160 \mathrm{MgCha}^{-1}\right)$, while the $\mathrm{C}$ stocks in Shark Bay's hotspots compare with those of mangroves and boreal forests $\left(255 \mathrm{MgCha}^{-1}\right.$ and $296 \mathrm{MgCha}^{-1}$, respectively) ${ }^{6,28}$. Assuming that the $\mathrm{C}$ stocks in the surveyed area are representative of the entire seagrass extent $\left(4,300 \mathrm{~km}^{2}\right)$, we estimated that seagrass sediments at Shark Bay contained a total of $55 \pm 3 \mathrm{TgC}$ in the top metre, which is equivalent to $0.65-1.3 \%$ of the total $\mathrm{C}$ stored in seagrass sediments worldwide $(4.2-8.4 \mathrm{PgC})^{6}$.

These estimates are limited to the upper metre of seagrass sediment $\mathrm{C}$ stocks (as are the global estimates) and, therefore, are probably underestimates of full $\mathrm{C}$ inventories since seagrass $\mathrm{C}$ deposits reach several metres in thickness in Shark $\mathrm{Bay}^{16}$. Seismic profiles combined with ${ }^{14} \mathrm{C}$ dating indicate that the seagrass banks here contain a continuous $4,000 \mathrm{yr}$ record of sediment and $\mathrm{C}$ accumulation ${ }^{16}$. This corresponds to an average sediment thickness of $3.1 \pm 0.4 \mathrm{~m}$, as indicated by long-term sediment accumulation rates estimated in this study (mean \pm s.e.m.: $0.77 \pm 0.11 \mathrm{~mm} \mathrm{yr}^{-1}$; Table 1 ), in agreement with vertical accretion rates of $\sim 1 \mathrm{~mm} \mathrm{yr}^{-1}$ published by oth$\operatorname{ers}^{16,29}$ and supported by the dominant seagrass $\delta^{13} \mathrm{C}$ signature of sediment $\mathrm{C}$ along the cores. Based on those, the $\mathrm{C}$ stocks accumulated over the last $4,000 \mathrm{cal} \mathrm{yr}$ вP averaged $334 \pm 34 \mathrm{MgCha}^{-1}$. Stocks were as high as $650 \mathrm{MgCha}^{-1}$ towards the south of the Wooramel Bank and Faure Sill, and decreased to $110 \mathrm{MgCha}^{-1}$ towards the northwest (Fig. 3b). Assuming that the average millenary $\mathrm{C}$ deposits studied here are representative throughout the entire seagrass extent $\left(4,300 \mathrm{~km}^{2}\right)$, the seagrass sediments in Shark Bay would have accumulated a total of $144 \pm 14 \mathrm{TgC}$ over the last $4,000 \mathrm{yr}$. While Mediterranean $P$. oceanica meadows have the highest sediment C stocks per unit area $\left(372 \pm 38 \mathrm{Mg} \mathrm{C} \mathrm{ha}^{-1}\right.$ in the top metre ${ }^{6}$ and $1,027 \pm 314 \mathrm{MgCha}^{-1}$ over the last $4,000 \mathrm{yr} \mathrm{BP}^{27}$ ), the vast extent of Shark Bay's meadows makes their sediments the world's largest seagrass $\mathrm{C}$ stocks yet reported for a seagrass ecosystem.

\section{C sequestration in seagrass sediments}

Long-term (over 1,000 years) $\mathrm{C}$ accumulation rates in Shark Bay seagrass meadows ranged from 2.5 to $32.1 \mathrm{~g} \mathrm{C} \mathrm{m}^{-2} \mathrm{yr}^{-1}$, with a median of $11.3 \mathrm{~g} \mathrm{C} \mathrm{m}^{-2} \mathrm{yr}^{-1}$ (mean \pm s.e.m.: $12 \pm 2 \mathrm{C} \mathrm{m}^{-2} \mathrm{yr}^{-1}$ ), while 

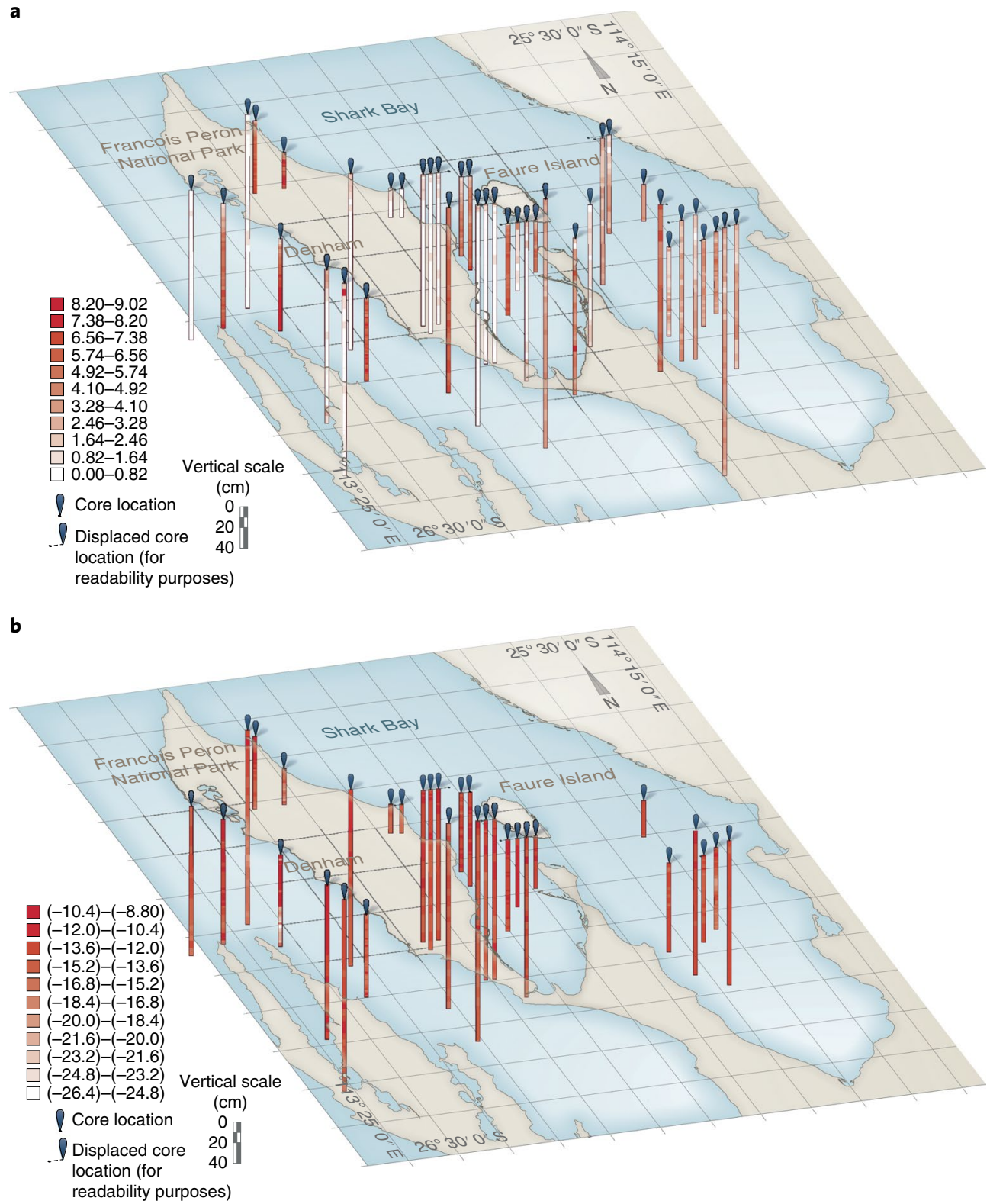

Fig. 2 | Spatial distribution of organic carbon in seagrass sediments of Shark Bay. a, b, Measured organic carbon content (percentage of C) (a) and $\delta^{13} \mathrm{C}$ stable isotopic signature of $\mathrm{C}(\mathbf{b})$ along the entire thickness of the sampled sediments. Average $\delta^{13} \mathrm{C}$ values for the main seagrass banks: Wooramel Bank: $-13.83 \pm 0.02 \%$; Faure Sill: $-13.0 \pm 0.1 \%$ Peron: $-13.4 \pm 0.1 \%$.

short-term accumulation rates (last 100 years) were estimated at 15 to $123 \mathrm{~g} \mathrm{C} \mathrm{m}^{-2} \mathrm{yr}^{-1}$, with a median of $30 \mathrm{~g} \mathrm{C} \mathrm{m}^{-2} \mathrm{yr}^{-1}$ (mean \pm s.e.m.: $46 \pm 13 \mathrm{~g} \mathrm{C} \mathrm{m}^{-2} \mathrm{yr}^{-1}$ ) (Table 1). These estimates are in the range of modern (that is, last $100 \mathrm{yr}$ ) $\mathrm{C}$ accumulation rates of $P$. oceanica in the Mediterranean ${ }^{30}, P$. australis in Australia ${ }^{31,32}$ and Thalassia testudinum in Florida Bay $^{33}\left(26-122 \mathrm{~g} \mathrm{C} \mathrm{m}^{-2} \mathrm{yr}^{-1}\right)$. Both the longand short-term $\mathrm{C}$ accumulation rates estimated here exceed those of terrestrial forest soils by 3 - to 10 -fold (average rates in forest soils: $\left.4.6 \pm 1 \mathrm{~g} \mathrm{C} \mathrm{m}^{-2} \mathrm{yr}^{-1}\right)^{1}$ and equal short-term $\mathrm{C}$ accumulation in Australian tidal marshes $\left(55 \pm 2 \mathrm{gC} \mathrm{m}^{-2} \mathrm{yr}^{-1}\right)^{34}$.

The $4,300 \mathrm{~km}^{2}$ of seagrass meadows in Shark Bay contemporarily account for a sequestration of $200 \pm 55 \mathrm{Gg} \mathrm{Cyr}^{-1}$ (range $65-527 \mathrm{GgC}^{-1}$ ), which represents $9 \%$ of the $\mathrm{C}$ sequestered by Australia's vegetated coastal ecosystems (occupying an area of $\left.110,000 \mathrm{~km}^{2}\right)^{7,34,35}$. This comparison highlights the disproportionate $\mathrm{C}$ sequestration capacity of Shark Bay seagrasses, contributing significantly to the $\mathrm{C}$ sequestration by seagrasses, mangroves and tidal marshes in Australia.

\section{$\mathrm{CO}_{2}$ emissions after seagrass loss}

Seagrass meadows in Shark Bay experienced extensive declines driven by the marine heatwave that impacted the coast of Western Australia in the austral summer 2010/2011 ${ }^{17}$. Mapping inside the Marine Park in 2014 revealed a net reduction of approximately $22 \%$ in seagrass habitat from the 2002 baseline (Fig. 4). The net loss of seagrass extent was accompanied by a dramatic shift in seagrass cover from dense to sparse across large areas of the bay, with dense seagrass areas declining from $72 \%$ in 2002 to $46 \%$ in 2014 (Table 2). Most losses occurred across the northern half of the western gulf, and at the northern part of the Wooramel Bank. After the event, water clarity decreased progressively and significantly due to the loss of sediment stabilization. In addition, widespread phytoplankton 


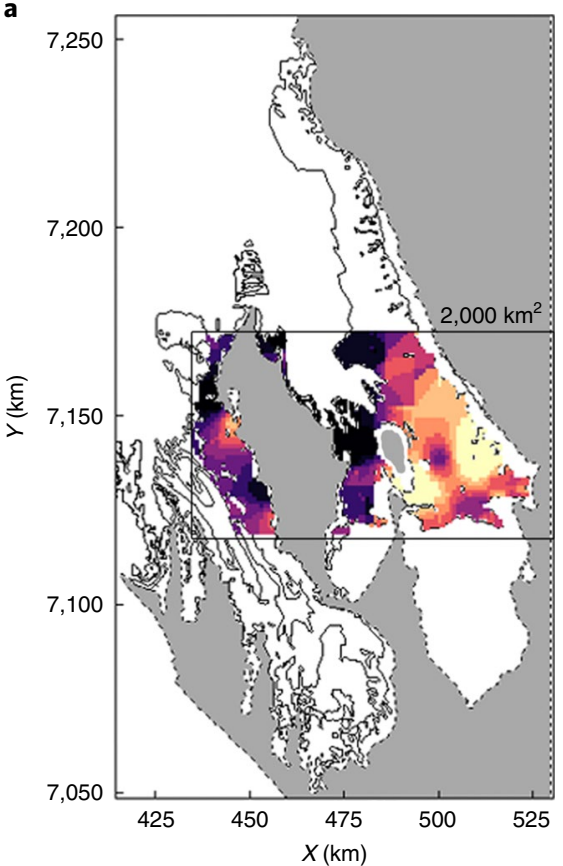

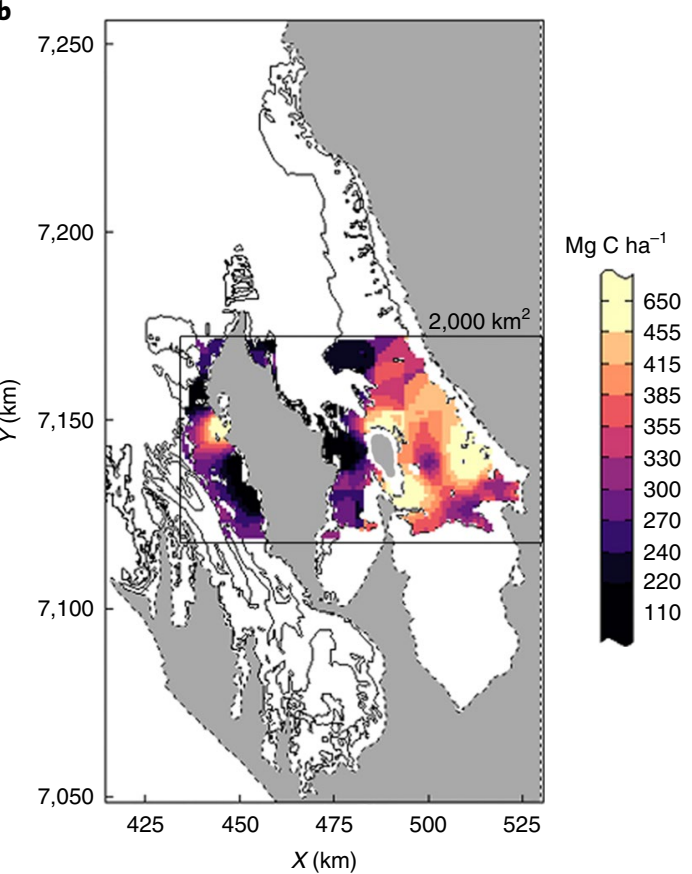

Fig. 3 Spatial distribution of organic carbon stocks in seagrass sediments of Shark Bay. $\mathbf{a}$, Top-metre $\mathbf{C}$ stocks. b, C stocks accumulated over the last 4,000 cal yr BP. The area with $C$ storage estimates covers $2,000 \mathrm{~km}^{2}$ of seagrass sediments. The integrated sediment $C$ stock within the $2,000 \mathrm{~km}^{2}$ of surveyed seagrass area was estimated at $24 \operatorname{Tg} C$ in the top metre and $64 \operatorname{Tg} C$ over the last 4,000 cal yr BP.

and bacterial blooms were observed in both gulfs of Shark Bay as a result of increased nutrient inputs to the water column from degraded seagrass biomass and sediment erosion ${ }^{13}$, providing favourable conditions for $\mathrm{CO}_{2}$ emissions ${ }^{36}$.

Losses of $\mathrm{C}$ and associated $\mathrm{CO}_{2}$ emissions following degradation of seagrass ecosystems have been documented previously ${ }^{20}$. Yet, no studies have evaluated the risk of $\mathrm{CO}_{2}$ emissions associated with seagrass loss due to thermal stress impacts. Carbon remineralization to $\mathrm{CO}_{2}$ is accelerated after disturbance through the decomposi- tion of dead biomass and from the alteration of the physical and/or biogeochemical environment in which the sediment $\mathrm{C}$ was stored ${ }^{36}$. Vegetation loss also increases the potential for sediment erosion and sediment resuspension in the water column ${ }^{37}$, increasing the oxygen exposure of previously buried sediment organic matter ${ }^{38}$, leading to two to four times higher remineralization of sediment $C$ under oxic than anoxic conditions ${ }^{20}$. Carbon in the upper metre of sediments has been considered the most susceptible to remineralization when seagrass meadows are lost ${ }^{4,6}$. However, it has recently been

Table 1 | Short- and long-term sedimentation, organic carbon $(C)$ accumulation rates and sediment $C$ stocks accumulated over the last 4,000 yr BP

\begin{tabular}{|c|c|c|c|c|c|}
\hline \multirow[t]{2}{*}{ Core ID } & \multicolumn{2}{|c|}{ Sedimentation rates $\left(\mathrm{mm} \mathrm{yr}^{-1}\right)$} & \multicolumn{2}{|c|}{$\mathrm{C}$ accumulation $\left(\mathrm{g} \mathrm{C} \mathrm{m}^{-2} \mathrm{yr}^{-1}\right)$} & \multirow{2}{*}{$\begin{array}{l}\text { Sediment } C \text { stocks } \\
4,000 \text { cal yr BP } \\
\left(\mathrm{Mg} \mathrm{Cha}^{-1}\right)\end{array}$} \\
\hline & $\begin{array}{l}\text { Short-term (last } \\
100 \mathrm{yr})\end{array}$ & $\begin{array}{l}\text { Long-term (last } 1,000- \\
6,000 \text { cal yr BP) }\end{array}$ & $\begin{array}{l}\text { Short-term (last } \\
100 \mathrm{yr})\end{array}$ & $\begin{array}{l}\text { Long-term (last } \\
1,000 \text { cal yr BP) }\end{array}$ & \\
\hline W3 & $2.3 \pm 0.9$ & $0.58 \pm 0.08$ & $77 \pm 41$ & $14.1 \pm 2.6$ & $369 \pm 51$ \\
\hline W4 & & $1.08 \pm 0.33$ & & $32.1 \pm 13.9$ & $1,338 \pm 390$ \\
\hline FS7 & $2.3 \pm 0.3$ & $1.48 \pm 0.06$ & $29 \pm 5$ & $12.9 \pm 0.7$ & \\
\hline FS9 & $1.7 \pm 0.1$ & $0.74 \pm 0.03$ & $27 \pm 3$ & $8.5 \pm 0.4$ & $304 \pm 12$ \\
\hline FS11 & $3.1 \pm 0.2$ & & $123 \pm 14$ & & \\
\hline FS13 & $2.6 \pm 0.2$ & $0.69 \pm 0.02$ & $25 \pm 3$ & $8.7 \pm 0.3$ & $528 \pm 14$ \\
\hline FS14 & $4.5 \pm 0.5$ & $1.31 \pm 0.07$ & $45 \pm 7$ & $15.2 \pm 1.2$ & \\
\hline P5 & & $0.43 \pm 0.05$ & & $6.7 \pm 0.3$ & $242 \pm 6$ \\
\hline P7 & & $0.66 \pm 0.02$ & & $11.3 \pm 0.3$ & $310 \pm 6$ \\
\hline P8 & & $0.39 \pm 0.02$ & & $2.5 \pm 0.1$ & $99 \pm 2$ \\
\hline P10 & $1.8 \pm 0.7$ & $0.39 \pm 0.01$ & $15 \pm 9$ & $6.4 \pm 0.3$ & $167 \pm 4$ \\
\hline P12 & $1.6 \pm 0.2$ & $0.74 \pm 0.03$ & $31 \pm 7$ & $16.8 \pm 1.1$ & $594 \pm 27$ \\
\hline Mean \pm s.e.m. & $2.5 \pm 0.3$ & $0.77 \pm 0.11$ & $46 \pm 13$ & $12 \pm 2$ & $439 \pm 124$ \\
\hline
\end{tabular}

Sedimentation and $\mathrm{C}$ accumulation rates were estimated by ${ }^{210} \mathrm{~Pb},{ }^{14} \mathrm{C}$ dating of sediments and the depth-weighted average of $\mathrm{C}$ concentrations (short-term normalized to $100 \mathrm{yr}$ depth, and long-term to 1,000 cal yr BP depth). The uncertainties represent the s.e.m. of the regression and the result of error propagation for sedimentation rates, and $\mathrm{C}$ accumulation rates and stocks, respectively. 

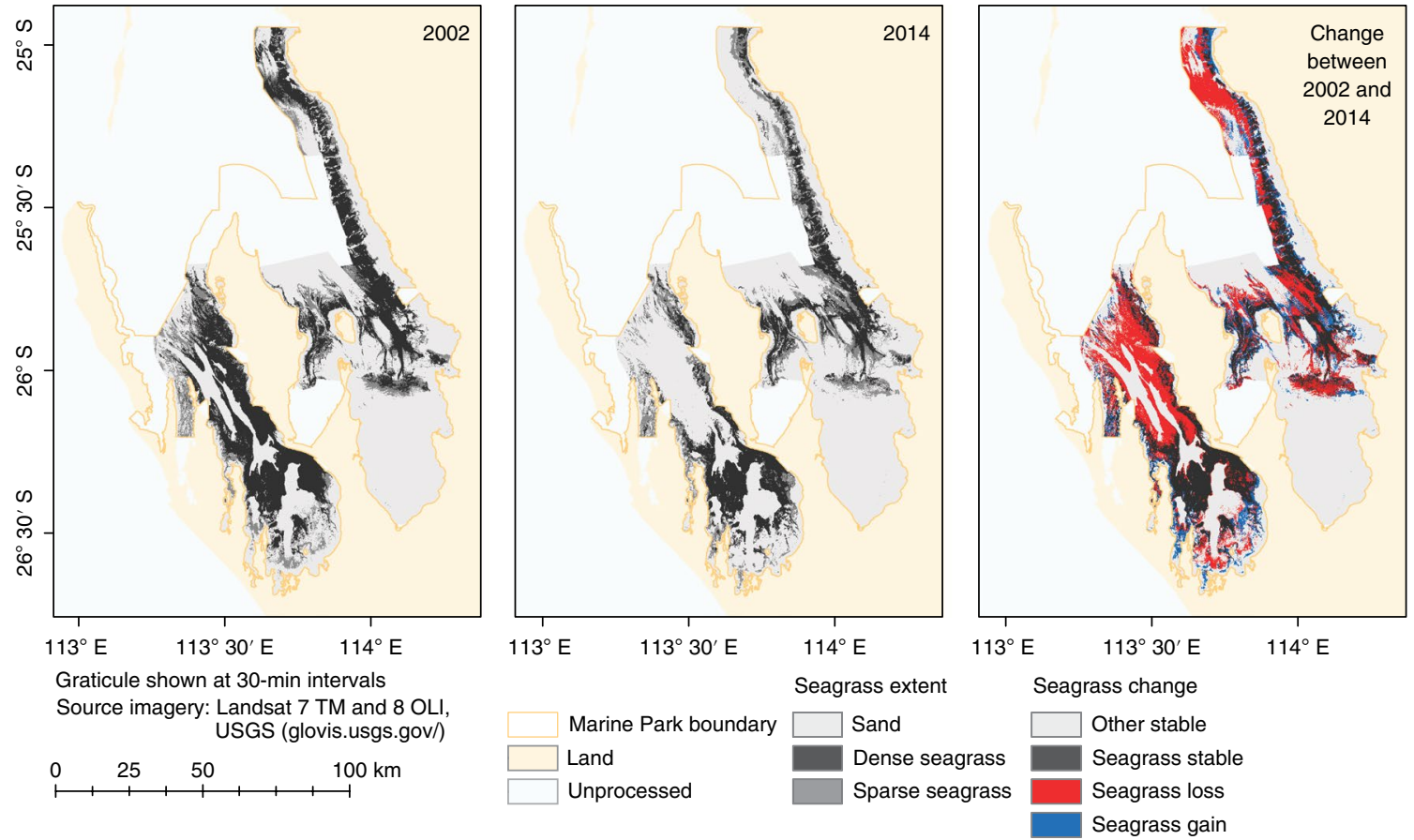

Fig. 4 | Seagrass extent change within Shark Bay's Marine Park before (2002) and after (2014) the marine heatwave in 2010/2011. Black, dense (>40\%) seagrass cover; grey, sparse (<40\%) seagrass cover; red, seagrass loss; dark blue, seagrass gain; light grey, sand; white, no data; gold, Marine Park boundary.

suggested that the proportions of the $C$ stock that may be exposed to oxic conditions after disturbance in seagrass ecosystems could be lower than previously assumed, probably due to their permanently submerged condition and lower levels of exposure to air $^{20}$. Assuming that between 10 and $50 \%$ of the seagrass sediment $\mathrm{C}$ stock is exposed to an oxic environment after disturbance (experiencing a decay of $0.183 \mathrm{yr}^{-1}$; ref. ${ }^{20}$ ), we estimate that between 4 and $22 \mathrm{MgCha}^{-1}$ (4-20\% of the $\mathrm{C}$ stock in the upper metre of sediments) might have been lost in Shark Bay from previously vegetated sediments during the first 3 years after the marine heatwave. This may have resulted in the net emission of $16-80 \mathrm{MgCO}_{2} \mathrm{eq} \mathrm{ha}^{-1}$, and assuming no seagrass recovery, it could result in cumulative $\mathrm{C}$ losses of 10 to $52 \mathrm{MgCha}^{-1}$ or $38-190 \mathrm{MgCO}_{2} \mathrm{eqha}^{-1}(10-50 \%$ of the $\mathrm{C}$ stock in the upper metre of sediments) 40 years after the event. In addition to accelerated sediment $\mathrm{C}$ loss, the reduced seagrass standing stock (that is, biomass) would in turn lead to a lower capacity of Shark Bay's seagrasses to sequester $\mathrm{C}$. The reduction in the modern $\mathrm{C}$ sequestration is estimated to be $0.46 \pm 0.13 \mathrm{MgChayr}^{-1}$, and $52 \pm 14 \mathrm{Gg} \mathrm{C} \mathrm{yr}^{-1}$ over the $\sim 1,100 \mathrm{~km}^{2}$ damaged area.

Excluding potential emissions from remineralization of seagrass biomass and extrapolating estimates per unit area to the total damaged seagrass area, we estimate that the widespread loss of seagrasses in Shark Bay in 2010/2011 may have resulted in $\mathrm{CO}_{2}$ emissions from sediment $\mathrm{C}$ stocks ranging from 2 to $9 \mathrm{TgCO}_{2}$ during the following 3 years after the event. This can be compared to the 14.4 $\mathrm{Tg} \mathrm{CO}_{2}$ estimated to be released annually from land-use change in Australia ${ }^{39}$, which did not account for emissions associated with seagrass losses, and hence would have increased the national landuse change estimate by $4 \%$ to $21 \%$ per annum. Cumulative emissions due to seagrass die-off could range between 4 and $21 \mathrm{TgCO}_{2}$ after 40 years, assuming no seagrass recovery during this period, a reasonable assumption given that the recovery of $A$. antarctica and $P$. australis has been shown to take decades $(>20 \mathrm{yr})^{40,41}$ or not occur over contemporary timescales ${ }^{13}$. If damaged seagrass meadows recover, the estimates of $\mathrm{CO}_{2}$ emissions after 40 years might be lower than reported here. In addition, $\mathrm{CO}_{2}$ emissions from organic carbon remineralization may be partially offset by the net dissolution of the underlying carbonate sediments ${ }^{42}$. On the other hand, decomposition rates of $\mathrm{C}$ may be enhanced in persistent vegetated and degraded areas due to increased seawater temperature that influences respiration ${ }^{43}$. However, the potential and magnitude of such effects is unclear, and therefore, they were not considered in this study.

\section{Building resilience for mitigation}

Conservation of seagrass meadows and their millenary sediment $\mathrm{C}$ deposits is an efficient strategy to mitigate climate change, through the preservation of seagrass $\mathrm{C}$ sequestration capacity, but especially through avoiding $\mathrm{CO}_{2}$ emissions from sediments following habitat degradation, which greatly surpass the annual sequestration capacity by undisturbed seagrass meadows. With increasing frequency of extreme events, there is a necessity to advance our understanding of how seagrass ecosystems, especially those living close to their thermal tolerance limit, will respond to global change threats, both direct and through interactive effects with local pressures. Local threats in Shark Bay include seagrass loss associated with turbidity and nutrient inputs from flooding of poorly managed pastoral leases, release of bitterns from a salt mine, changes in the trophic dynamics of the system through overfishing or targeted fishing, and more local damage to seagrasses from vessel propellers and anchors associated with growth in tourism. Current management at Shark Bay includes the declaration of special zones for seagrass protection, promoting public awareness of the significance of seagrass, and providing information on responsible boating (Shark Bay Marine Reserves Management Plan 1996-2006: https://www.dpaw.wa.gov. $\mathrm{au})$. These practices are well suited to localized stressors, such as eutrophication ${ }^{44}$, but less suited to managing global threats such as heatwaves, due to the spatial scale and magnitude of these impacts ${ }^{45}$.

In the face of global threats, management can aim to maintain or enhance the resilience of seagrasses ${ }^{46}$. The heatwave-associated seagrass die-off in 2010/2011 mostly affected A. antarctica followed by $P$. australis, which are persistent seagrasses with slow growth rates 
Table 2 | Effects of the marine heatwave event on seagrass area and organic carbon (C) stocks under degraded seagrass meadows

\begin{tabular}{|c|c|c|}
\hline & Marine Park area $\left(8,900 \mathrm{~km}^{2}\right)$ & Extrapolated values for the entire bay $\left(13,000 \mathrm{~km}^{2}\right)$ \\
\hline Baseline seagrass area $\left(\mathrm{km}^{2}\right)$ & 2,689 & 4,300 \\
\hline Dense & 1,925 & 3,096 \\
\hline C stock top metre $(\operatorname{Tg} C)$ & $34 \pm 14$ & $55 \pm 22$ \\
\hline Seagrass area loss $\left(\mathrm{km}^{2}\right)$ & 581 & 929 \\
\hline Shift to sparse seagrass $\left(\mathrm{km}^{2}\right)$ & 118 & 190 \\
\hline \multicolumn{3}{|c|}{3 yr net $C$ loss from $1 \mathrm{~m}$ sediment stock $(\mathrm{Tg} C$ ) } \\
\hline$\alpha \quad 0.10$ & $0.30 \pm 0.05$ & $0.49 \pm 0.08$ \\
\hline$\alpha \quad 0.25$ & $0.76 \pm 0.10$ & $1.23 \pm 0.15$ \\
\hline$\alpha \quad 0.50$ & $1.52 \pm 0.17$ & $2.45 \pm 0.27$ \\
\hline \multicolumn{3}{|c|}{40 yr net $C$ loss from $1 \mathrm{~m}$ sediment stock $(\mathrm{Tg} C)^{\mathrm{a}}$} \\
\hline $3 \mathrm{yr}$ net $\mathrm{CO}_{2}$ emissions $\left(\mathrm{TgCO}_{2}\right)$ & $1.1-5.6$ & $1.8-9.0$ \\
\hline 40 yr potential $\mathrm{CO}_{2}$ emissions $\left(\mathrm{TgCO}_{2}\right)^{\mathrm{a}}$ & $2.6-13.2$ & $4.3-21.3$ \\
\hline
\end{tabular}

$\alpha$ is the fraction of sediment $\mathrm{C}$ stock within the top metre exposed to oxic conditions. A range of $\alpha=0.10-0.5$ was used to estimate $\mathrm{CO}_{2}$ emissions 3 and 40 years after the event. Biomass $\mathrm{C}$ loss is not included in the calculations as much of the primary production might be buried or exported, rather than remineralized in situ. ${ }^{2}$ Loss and emission after 40 years of disturbance assuming no seagrass recovery.

but capable of building large stores of carbohydrates in their rhizomes $^{41}$. These characteristics provide the species with high levels of resistance to disturbance ${ }^{11,12}$. However, once lost, their capacity to recover is limited and slow, and largely depends on the immigration of seeds or seedlings. Therefore, conservation actions to preserve these seagrass meadows, thereby maintaining their $\mathrm{C}$ sequestration capacity and avoiding greenhouse gas emissions ${ }^{36}$, should primarily aim to avoid the loss of vegetative material and prevent local pressures exacerbating those of global change to enhance their resilience. Actions following acute disturbance could include the removal of seagrass detritus after die-off to reduce detritus loading, lessening the threat of acute eutrophication; and the restoration of impacted areas using seed-based restoration approaches such as the movement of seeds and viviparous seedlings to impacted sites or the provision of anchoring points in close proximity to donor seagrass meadows to enhance recover $y^{47,48}$. Long-term actions should include management to maintain top-down controls so that herbivory is maintained at natural levels ${ }^{49}$. More contentious actions could aim to repopulate areas with more resilient seagrass genotypes sourced from outside the impacted sites ${ }^{50}$. The wide range of salinity and temperature in the Bay, together with the uneven loss of meadows following the event in 2010/2011, may indicate differences in adaptation and resilience among meadows across the Bay. This offers the possibility of identifying heatwave-resistant genotypes and using these to supplement the genetic diversity and resilience of existing meadows. Genotypic mapping could also allow identification of the meadows at greatest risk of heatwaves where management actions may be focused.

Our results show that seagrass meadows from Shark Bay support the largest seagrass $\mathrm{C}$ stocks worldwide, and that while making a large contribution to $C$ sequestration by vegetated coastal ecosystems, their loss may disproportionately add to Australian $\mathrm{CO}_{2}$ emissions. With increasing frequency and intensity of extreme climate events, the permanence of these $\mathrm{C}$ stores might be compromised, further stressing the importance of reducing greenhouse gas emis- sions, and implementing management actions to enhance and preserve natural carbon sinks.

\section{Methods}

Methods, including statements of data availability and any associated accession codes and references, are available at https://doi. org/10.1038/s41558-018-0096-y.

Received: 19 September 2017; Accepted: 1 February 2018; Published online: 19 March 2018

\section{References}

1. McLeod, E. et al. A blueprint for blue carbon: Toward an improved understanding of the role of vegetated coastal habitats in sequestering $\mathrm{CO}_{2}$. Front. Ecol. Environ. 9, 552-560 (2011).

2. Duarte, C. M., Losada, I. J., Hendriks, I. E., Mazarrasa, I. \& Marbà, N. The role of coastal plant communities for climate change mitigation and adaptation. Nat. Clim. Change 3, 961-968 (2013).

3. IPCC Climate Change 2014: Mitigation of Climate Change (eds Edenhofer, O. et al.) (Cambridge Univ. Press, Cambridge, UK, 2014).

4. Pendleton, L. et al. Estimating global 'blue carbon' emissions from conversion and degradation of vegetated coastal ecosystems. PLoS One 7, e43542 (2012).

5. Short, F., Polidoro, B. \& Livingstone, S. Extinction risk assessment of the world's seagrass species. Biol. Conserv. 144, 1961-1971 (2011).

6. Fourqurean, J. W. et al. Seagrass ecosystems as a globally significant carbon stock. Nat. Geosci. 5, 505-509 (2012).

7. Lavery, P. S., Mateo, M. Á., Serrano, O. \& Rozaimi, M. Variability in the carbon storage of seagrass habitats and its implications for global estimates of blue carbon ecosystem service. PLoS One 8, e73748 (2013).

8. Serrano, O. et al. Key biogeochemical factors affecting soil carbon storage in Posidonia meadows. Biogeosciences 13, 4581-4594 (2016).

9. Waycott, M. et al. Accelerating loss of seagrasses across the globe threatens coastal ecosystems. Proc. Natl Acad. Sci. USA 106, 12377-12381 (2009).

10. Marbà, N. \& Duarte, C. M. Mediterranean warming triggers seagrass (Posidonia oceanica) shoot mortality. Glob. Change Biol. 16, 2366-2375 (2009).

11. Fraser, M. W., Kendrick, G. A., Statton, J., Hovey, R. K. \& Walker, D. I Extreme climate events lower resilience of foundation seagrass at edge of biogeographical range. J. Ecol. 102, 1528-1536 (2014). 
12. Thomson, J. A. et al. Extreme temperatures, foundation species, and abrupt ecosystem change: an example from an iconic seagrass ecosystem. Glob. Change Biol. 21, 1463-1474 (2014).

13. Nowicki, R., Thomson, J. A., Burkholder, D. A., Fourqurean, J. W. \& Heithaus, M. Predicting seagrass recovery times and their implications following an extreme climate event. Mar. Ecol. Prog. Ser. 567, 79-93 (2017).

14. Walker, B., Holling, C. \& Carpenter, S. Resilience, adaptability and transformability in social-ecological systems. Ecol. Soc. 9, 5 (2004).

15. Walker, D., Kendrick, G. \& McComb, A. The distribution of seagrass species in Shark Bay, Western Australia, with notes on their ecology. Aquat. Bot. 30 305-317 (1988).

16. Bufarale, G. \& Collins, L. B. Stratigraphic architecture and evolution of a barrier seagrass bank in the mid-late Holocene, Shark Bay, Australia. Mar. Geol. 359, 1-21 (2015).

17. Wernberg, T. et al. An extreme climatic event alters marine ecosystem structure in a global biodiversity hotspot. Nat. Clim. Change 3, 78-82 (2012).

18. Pearce, A. \& Feng, M. Observations of warming on the Western Australian continental shelf. Mar. Freshw. Res. 58, 914-920 (2007).

19. Arias-Ortiz, A. et al. A Marine Heat Wave Drives Massive Losses from the World's Largest Seagrass Carbon Stocks (Edith Cowan University, 2017); https://doi.org/10.4225/75/5a1640e851af1

20. Lovelock, C. E., Fourqurean, J. W. \& Morris, J. T. Modeled $\mathrm{CO}_{2}$ emissions from coastal wetland transitions to other land uses: tidal marshes, mangrove forests, and seagrass beds. Front. Mar. Sci. 4, 1-11 (2017).

21. Burkholder, D. A., Heithaus, M. R., Thomson, J. A. \& Fourqurean, J. W. Diversity in trophic interactions of green sea turtles Chelonia mydas on a relatively pristine coastal foraging ground. Mar. Ecol. Prog. Ser. 439, 277-293 (2011).

22. Cawley, K. M., Ding, Y., Fourqurean, J. \& Jaffé, R. Characterising the sources and fate of dissolved organic matter in Shark Bay, Australia: A preliminary study using optical properties and stable carbon isotopes. Mar. Freshw. Res. 63, 1098-1107 (2012).

23. Kennedy, H. et al. Seagrass sediments as a global carbon sink: Isotopic constraints. Glob. Biogeochem. Cycles 24, 1-9 (2010).

24. Trevathan-Tackett, S. M. et al. Comparison of marine macrophytes for their contributions to blue carbon sequestration. Ecology $\mathbf{9 6}$ 3043-3057 (2015)

25. Laursen, A. K., Mayer, L. M. \& Townsend, D. W. Lability of proteinaceous material in estuarine seston and subcellular fractions of phytoplankton. Mar Ecol. Prog. Ser. 136, 227-234 (1996).

26. Enríquez, S., Duarte, C. M. \& Sand-Jensen, K. Patterns in decomposition rates among photosynthetic organisms: the importance of detritus C:N:P content. Oecologia 94, 457-471 (1993).

27. Serrano, O., Lavery, P. S., López-Merino, L., Ballesteros, E. \& Mateo, M. A. Location and associated carbon storage of erosional escarpments of seagrass Posidonia mats. Front. Mar. Sci. 3, 42 (2016).

28. Prentice, I. et al. in Climate Change 2001: The Scientific Basis (eds Houghton, J. T. et al.) 185-237 (IPCC, Cambridge Univ. Press, 2001).

29. Davis, G. in Carbonate Sedimentation and Environments, Shark Bay, Western Australia Vol. 13 (eds Logan, B. W. et al.) 169-205 (Memoirs, American Association of Petroleum Geologists, Tulsa, OK, USA, 1970).

30. Mazarrasa, I. et al. Effect of environmental factors (wave exposure and depth) and anthropogenic pressure in the $\mathrm{C}$ sink capacity of Posidonia oceanica meadows. Limnol. Oceanogr. 62, 1436-1450 (2017).

31. Marbà, N. et al. Impact of seagrass loss and subsequent revegetation on carbon sequestration and stocks. J. Ecol. 103, 296-302 (2015).

32. Serrano, O. et al. Impact of mooring activities on carbon stocks in seagrass meadows. Sci. Rep. 6, 23193 (2016)

33. Orem, W. H. et al. Geochemistry of Florida Bay sediments: nutrient history at five sites in eastern and central Florida Bay. J. Coast. Res. 15, 1055-1071 (1999).

34. Macreadie, P. I. et al. Carbon sequestration by Australian tidal marshes. Sci. Rep. 7, 44071 (2017)

35. Atwood, T. B. et al. Global patterns in mangrove soil carbon stocks and losses. Nat. Clim. Change 7, 523-528 (2017).

36. Lovelock, C. E. et al. Assessing the risk of carbon dioxide emissions from blue carbon ecosystems. Front. Ecol. Environ. 15, 257-265 (2017).

37. van der Heide, T., van Nes, E. H., van Katwijk, M. M., Olff, H. \& Smolders, A. J. P. Positive feedbacks in seagrass ecosystems - Evidence from large-scale empirical data. PLoS ONE 6, 1-7 (2011)

38. Burdige, D. J. Preservation of organic matter in marine sediments: Controls, mechanisms, and an imbalance in sediment organic carbon budgets? Chem. Rev. 107, 467-485 (2007)

39. Haverd, V. et al. The Australian terrestrial carbon budget. Biogeosciences 10, 851-869 (2013).
40. Cambridge, M. L., Bastyan, G. R. \& Walker, D. I. Recovery of Posidonia meadows in Oyster Harbour, southwestern Australia. Bull. Mar. Sci. 71 1279-1289 (2002).

41. Marbá, N. \& Walker, D. I. Growth, flowering, and population dynamics of temperate Western Australian seagrasses. Mar. Ecol. Prog. Ser. 184, 105-118 (1999).

42. Burdige, D. J., Zimmerman, R. C. \& Hu, X. Rates of carbonate dissolution in permeable sediments estimated from pore-water profiles: The role of sea grasses. Limnol. Oceanogr. 53, 549-565 (2008).

43. Pedersen, M., Serrano, O. \& Mateo, M. Temperature effects on decomposition of a Posidonia oceanica mat. Aquat. Microb. Ecol. 65, 169-182 (2011).

44. Tomasko, D. A., Corbett, C. A., Greening, H. S. \& Raulerson, G. E. Spatial and temporal variation in seagrass coverage in Southwest Florida: assessing the relative effects of anthropogenic nutrient load reductions and rainfall in four contiguous estuaries. Mar. Pollut. Bull. 50, 797-805 (2005).

45. Björk, M, Short, F. T, Mcleod, E. \& Beer, S. Managing Seagrasses for Resilience to Climate Change . Resilience Science Group Working Paper No. 3. (IUCN: Gland, 2008.

46. Kilminster, K. et al. Unravelling complexity in seagrass systems for management: Australia as a microcosm. Sci. Total Environ. 534, 97-109 (2015).

47. Tanner, J. E. Restoration of the seagrass Amphibolis antarctica-Temporal variability and long-term success. Estuaries Coasts 38, 668-678 (2015).

48. Rivers, D. O., Kendrick, G. A. \& Walker, D. I. Microsites play an important role for seedling survival in the seagrass Amphibolis antarctica. J. Exp. Mar. Bio. Ecol. 401, 29-35 (2011).

49. Atwood, T. B. et al. Predators help protect carbon stocks in blue carbon ecosystems. Nat. Clim. Change 5, 1038-1045 (2015).

50. Hancock, N. \& Hughes, L. Turning up the heat on the provenance debate: Testing the 'local is best' paradigm under heatwave conditions. Austral Ecol. 39, 600-611 (2014).

66. Department of Biodiversity, Conservation and Attractions Marine Habitats of Western Australia. 2nd edn, (Western Australia Government: Perth, Australia, 2016)

\section{Acknowledgements}

This work was supported by the CSIRO Flagship Marine and Coastal Carbon Biogeochemical Cluster with funding from the CSIRO Flagship Collaboration Fund and by King Abdullah University of Science and Technology through the baseline funding to C.M.D., P.M. and A.A.-O., and M.A.M. acknowledge the support by the Generalitat de Catalunya (grants 2014 SGR-1356 and 2014 SGR-120, respectively). This work is contributing to the ICTA 'Unit of Excellence' (MinECo, MDM2015-0552) and is contribution no. 78 from the Marine Education and Research Center at the Institute for Water and Environment at Florida International University. A.A.-O. was supported by a PhD scholarship from Obra Social 'LaCaixa'. O.S. was supported by an ARC DECRA DE170101524. M.R. was supported by the Research University grant UKM-DIP-2017-005. N.M. was supported by a Gledden Visiting Fellowship of IASUWA and the Medshift project (CGL2015-71809-P) and J.W.F. was supported by the US National Science Foundation through the Florida Coastal Everglades Long-Term Ecological Research programme (grant DEB-1237517). Partial laboratory analysis was supported by the Hodgkin Trust Top-up Scholarship 2013 awarded to M.R. We thank G. Bufarale and L. Collins for their assistance in collecting the cores and C.X. Pita, King Abdullah University of Science and Technology (KAUST), for the artwork in Fig. 2 and Supplementary Fig. 1. Seagrass spatial distribution in Fig. 1 from the Department of Biodiversity, Conservation and Attractions of Western Australia.

\section{Author contributions}

O.S., P.L., G.A.K. and C.M.D. designed the study. A.A.O., O.S., M.R., A.E. and N.M. carried out field and/or laboratory measurements. U.M. derived geostatistical models and A.A.O. and P.M. derived dating models. K.M. and M.R. mapped seagrass area. J.W.F and M.A.M. contributed data. A.A.O. analysed the data and drafted the first version of the manuscript. All authors contributed to the writing and editing of the manuscript.

\section{Competing interests}

The authors declare no competing interests.

\section{Additional information}

Supplementary information accompanies this paper at https://doi.org/10.1038/s41558018-0096-y.

Reprints and permissions information is available at www.nature.com/reprints.

Correspondence and requests for materials should be addressed to A.A.

Publisher's note: Springer Nature remains neutral with regard to jurisdictional claims in published maps and institutional affiliations. 


\section{Methods}

Seagrass sediments were sampled using polyvinyl chloride (PVC) corers (100$300 \mathrm{~cm}$ long, $6.5 \mathrm{~cm}$ internal diameter) that were hammered into the substrate at 0.5 to $4 \mathrm{~m}$ water depth. In the laboratory, the PVC corers were cut lengthwise, and the sediments inside the corers were sliced at 1- or 3-cm-thick intervals. Analyses of ${ }^{210} \mathrm{~Pb},{ }^{14} \mathrm{C}$ and grain size were conducted in cores cut at $1 \mathrm{~cm}$ resolution (11 cores), while dry bulk density, percentage of $\mathrm{C}$ and $\delta^{13} \mathrm{C}$ were measured in all cores $(28$ cores) in alternate slices every $3 \mathrm{~cm}$ (upper $50 \mathrm{~cm}$ ), and every $6 \mathrm{~cm}$ (below $50 \mathrm{~cm}$ ). We combined our data with previously published studies in Shark Bay involving coring in seagrass sediments ${ }^{7,16,51}$. From ref. ${ }^{16}$, we took core FDW2 (here W4) dated by ${ }^{14} \mathrm{C}$ and we analysed grain size, percentage of $\mathrm{C}$ and $\delta^{13} \mathrm{C}$ to include it in the data set. From ref. ${ }^{51}$, we included the $\mathrm{C}$ data from the eight long sediment cores (here W5-W8 and FS15-FS18) and from ref. ${ }^{7}$ we included $\mathrm{C}$ and ${ }^{13} \mathrm{C}$ data for twelve 27-cm-long cores (here P1 and P2) in this study ${ }^{19}$. Compression of seagrass sediments during coring was corrected by distributing the spatial discordances proportionally between the expected and the observed sediment column layer ${ }^{52}$ and was accounted for in the calculations of $\mathrm{C}$ stocks standardized to $1 \mathrm{~m}$ depth and $4,000 \mathrm{cal} \mathrm{yr} \mathrm{BP.} \mathrm{Average} \mathrm{compression} \mathrm{was} 20 \%$ and was applied to published data where compression existed but was not measured during sampling ${ }^{7,16}$. Published and unpublished cores from this study comprised 49 locations covering a range of 3 seagrass genera forming monospecific and mixed meadows, and 34 contained data deeper than 1 metre with 23 sites extending down to 2-3 metres (Supplementary Table 3). None of the cores penetrated the entire thickness of seagrass-accumulated sediment estimated to range from 4 to $6 \mathrm{~m}\left(\right.$ ref. $\left.{ }^{16}\right)$.

The $\mathrm{C}$ content of sediments was measured in pre-acidified (with $1 \mathrm{M} \mathrm{HCl}$ ) samples. One gram of ground sample was acidified to remove inorganic carbon after weighing, centrifuged (3,400 r.p.m., for $5 \mathrm{~min}$; Heraeus Megafuge 8,

TX-150 rotor) and the supernatant with acid residues was carefully removed by pipette, avoiding resuspension. The sample was then washed with Milli-Q water, centrifuged and the supernatant removed. The residual samples were then re-dried at $60^{\circ} \mathrm{C}$ and encapsulated in tin capsules for $\mathrm{C}$ and $\delta^{13} \mathrm{C}$ analyses using an elemental analyser-isotope ratio mass spectrometer (Hilo Analytical Laboratory) at the University of Hawaii. $\mathrm{C}$ content (percentage of $\mathrm{C}$ ) was calculated for the bulk (pre-acidified) samples using the formula $\left(\mathrm{C}_{\text {bulk }}=\mathrm{C}_{\text {acidified }} \times \frac{\text { mass acidified }}{\text { mass pre }- \text { acidified }}\right)$. The method used to remove inorganic carbon before $\mathrm{C}$ analyses may lead to the loss of part of the organic $\mathrm{C}$ (soluble fraction), thereby potentially leading to an underestimation of sediment $C$ content ${ }^{53,54}$. The sediment $\delta^{13} \mathrm{C}$ signature is expressed as $\delta$ values in parts per thousand relative to the Vienna PeeDee Belemnite. Replicate assays and standards indicated measurement errors of $\pm 0.04 \%$ and $\pm 0.1 \%$ for $\mathrm{C}$ content and $\delta^{13} \mathrm{C}$, respectively. The relative contribution of seagrass, macroalgae and seston (which includes living and non-living matter in the water column) and terrestrial matter to seagrass top-metre sediment carbon pools was computed by applying a three-component isotope-mixing model as described previously and calculated by means of the IsoSource Visual Basic program ${ }^{55}$, using a $1 \%$ increment and $0.1 \%$ tolerance. We used literature values for putative $\mathrm{C}$ sources, and macroalgae and seston were combined as a single $\mathrm{C}$ source since their published $\delta^{13} \mathrm{C}$ endmembers were not significantly different (Supplementary Table 2).

Sediment grain size was measured with a Mastersizer 2000 laser diffraction particle analyser following digestion of bulk samples with $10 \%$ hydrogen peroxide at the Centre for Advanced Studies of Blanes. The $d_{50}$ (that is, the median particle diameter) was used as a proxy for the particle size distribution. Sediments were classified as sand $(0.063-1 \mathrm{~mm})$, silt $(0.004-0.063 \mathrm{~mm})$ and clay $(<0.004 \mathrm{~mm})$, and the mud fraction was calculated as the sum of the fractions of silt and clay $(<0.063 \mathrm{~mm})$ (size scale: Wentworth, 1922 $)^{56}$. Sand/mud ratio was used as a proxy for depositional conditions and hydrodynamic energy, where higher sand content could be associated with higher-energy environments ${ }^{57}$.

Spearman correlation tests were used to assess significant relationships between $\mathrm{C}$ concentrations and environmental (that is, dry bulk density, $d_{50}$, percentage of sand, percentage of mud and sand/mud ratio) and biological (that is, percentage of $\mathrm{C}$ and $\mathrm{S}^{13} \mathrm{C}$ ) variables measured in seagrass sediment cores as none of the variables followed a normal distribution (Supplementary Table 1).

Eleven sediment cores were analysed for ${ }^{210} \mathrm{~Pb}$ concentrations to determine recent (about 100 years) sediment accumulation rates. ${ }^{210} \mathrm{~Pb}$ was determined through the analysis of ${ }^{210} \mathrm{Po}$ by alpha spectrometry after the addition of ${ }^{209} \mathrm{Po}$ as an internal tracer and digestion in acid media using an analytical microwave ${ }^{58}$. The concentrations of excess ${ }^{210} \mathrm{~Pb}$ used to obtain the age models were determined as the difference between total ${ }^{210} \mathrm{~Pb}$ and ${ }^{226} \mathrm{Ra}$ (supported ${ }^{210} \mathrm{~Pb}$ ). Concentrations of ${ }^{226} \mathrm{Ra}$ were determined for selected samples along each core by a low-background liquid scintillation counting method (Wallac 1220 Quantulus) adapted from a previous study $\mathrm{y}^{59}$. Mean sediment accumulation rates over the last 100 years could be estimated for eight out of the eleven sediment cores dated using the constant flux: constant sedimentation (CF:CS) model below the surface mixed layer when present ${ }^{60}$. Mixing was common from 0 to $4 \mathrm{~cm}$ in half of the dated sediment cores; hence, average modern accumulation rates should be considered as upper limits. Two to five samples of shells per core from the cores dated by ${ }^{210} \mathrm{~Pb}$ were also radiocarbon-dated at the Direct AMS-Radiocarbon Business Unit, Accium Biosciences, USA, following standard procedures ${ }^{61}$. The conventional radiocarbon ages reported by the laboratory were converted into calendar dates (cal yr вр) using the Bacon software (Marine13 curve) ${ }^{62}$ and applying a marine reservoir correction (that is, subtracting Delta R value of $85 \pm 30$ for the east Indian Ocean, Western Australia ${ }^{63}$. Average short-term $\mathrm{C}$ accumulation rates were estimated by multiplying sediment accumulation rates $\left(\mathrm{g} \mathrm{cm}^{-2} \mathrm{yr}^{-1}\right)$ by the fraction of $\mathrm{C}$ accumulated to $100 \mathrm{yr}$ depth determined by ${ }^{210} \mathrm{~Pb}$ dating. Bacon model output was used to estimate average long-term sediment accumulation rates $\left(\mathrm{g} \mathrm{cm}^{-2} \mathrm{yr}^{-1}\right)$ during the last $1,000 \mathrm{yr}$ вр. Long-term $\mathrm{C}$ accumulation rates were determined following the same method as for short-term accumulation rates, but the fraction of $\mathrm{C}$ was normalized to $1,000 \mathrm{cal}$ yr $\mathrm{BP}$, as the minimum age of the ${ }^{14} \mathrm{C}$-dated bottom sediments was $1,117 \pm 61$ cal yr вP (Supplementary Table 4 ).

C stocks at the 49 locations were estimated for $1 \mathrm{~m}$ sediment thickness and for a period of accumulation of 4,000 years, similar to the time of formation of the $\mathrm{C}$ deposits ${ }^{16}$. We standardized the estimates of sediment $\mathrm{C}$ stocks to 1-m-thick deposits since this allows comparisons with estimates of global stocks. Where necessary (that is, in 15 cores), we inferred C stocks below the limits of the reported data to $1 \mathrm{~m}$, extrapolating linearly integrated values of $\mathrm{C}$ content (cumulative $\mathrm{C}$ stock $\mathrm{MgCha}^{-1}$ ) with depth. C content was reported to at least $27 \mathrm{~cm}$ in 12 cores out of these 15 , while the other 3 cores had $\mathrm{C}$ data down to $55-83 \mathrm{~cm}$. Correlation between extrapolated C stocks from $27 \mathrm{~cm}$ to $1 \mathrm{~m}$ and measured C stocks in sediment cores $\geq 1 \mathrm{~m}$ was $\rho=0.82, P<0.001$ (Supplementary Fig. 3a). Sediment C stocks in the $\geq 1 \mathrm{~m}$ cores ranged from 23 to $322 \mathrm{MgCha}^{-1}$, with a mean value of $116 \pm 13 \mathrm{MgCha}^{-1}$ and median of $109 \mathrm{MgCha}^{-1}$. Extrapolating data on cumulative $C$ stocks from cores of at least $27 \mathrm{~cm}$ depth at a further 15 sites to $1 \mathrm{~m}$, we estimated C storage at those sites to range between 26 and $313 \mathrm{MgCha}^{-1}$, similar to sites with full inventories. Combining the estimates extrapolated from shallow cores with full core inventories, the resulting mean and median sediment C storage (103 $\pm 11 \mathrm{MgCha}^{-1}$ and $73 \mathrm{MgCha}^{-1}$, respectively) (Supplementary Fig. 4) were not significantly different $(P>0.05)$ from those for full core inventories. We applied ordinary kriging to estimate the top-metre $C$ stocks across $2,000 \mathrm{~km}^{2}$ encompassing the South Wooramel Bank, Faure Sill and Peron Peninsula seagrass banks $^{6,65}$. We used a maximum of the 16 nearest neighbours within a search circle of radius $25 \mathrm{~km}$. Ordinary kriging inherently declusters the input data and produces smoothed estimates, so that the extremely high or low values found within seagrass meadows of the Bay do not unduly influence the global mean.

We estimated seagrass sediment $C$ stocks accumulated over the last 4,000 years in 1- to $3-\mathrm{m}$-long cores where ${ }^{14} \mathrm{C}$ data were available and the length sampled embraced $\geq 2,000 \mathrm{yr}$ of sediment and $\mathrm{C}$ accumulation (that is, in 8 cores). The correlation between extrapolated and measured C stocks was $r=0.90$ $(P<0.05)$ (Supplementary Fig. 3b). Bay-wide estimates of sediment $C$ stocks accumulated over 4,000 cal yr BP were estimated by combining extrapolated and full 4,000 cal yr BP core inventories, and applying collocated co-kriging with topmetre $\mathrm{C}$ stocks as the secondary variable. Correlation between top-metre and 4,000 -yr-BP carbon stocks was $0.6(P<0.01)$ and the percentage of noise specific to the background was set to $20 \%$. Spatial variability of $\mathrm{C}$ stocks was mapped after applying ordinary kriging to top-metre $\mathrm{C}$ stocks and collocated co-kriging to millenary C stocks ( 4,000 cal yr BP).

Data on seagrass sediment $\mathrm{C}$ stocks accumulated during the last $4,000 \mathrm{yr}$ in P. oceanica were extracted or extrapolated from published estimates ${ }^{27}$ of sediment cores with a sampled depth of at least $2,000 \mathrm{yr}$, as this is the same method we used to estimate long-term $\mathrm{C}_{\text {org }}$ stocks at Shark Bay.

The extent of seagrass meadows in Shark Bay before and after the extreme climatic event was determined by the Western Australian Department of Biodiversity, Conservation and Attractions as part of a broader long-term seagrass monitoring programme. Seagrass extent was derived using a supervised classification of imagery captured by Landsat -5 Thematic Mapper (TM) in 2002 and Landsat-8 Operational Land Imager (OLI) in 2014 (United States Geological Survey (glovis.usgs.gov/)). The spatial resolution of these images is $30 \mathrm{~m}$. The 2002 and 2014 classifications used a combination of historical ground-truthing, long-term monitoring data and expert knowledge for training sites and validation. The imagery was classified into three distinct classes: dense seagrass ( $>40 \%$ cover); sparse seagrass $(<40 \%$ cover); and other (which included all remaining habitat types). The Shark Bay Marine Park covers approximately $8,900 \mathrm{~km}^{2}$ of seafloor. The seagrass mapping presented here covers approximately $78 \%$ of the Shark Bay Marine Park. The entire extent was not mapped due to poor image quality caused by depth and water clarity and the lack of data in some areas.

Net seagrass area losses and shifts in seagrass cover from dense to sparse were considered as damaged areas, where the seagrass sediment organic matter is more exposed to oxygen due to erosion and sediment resuspension, and hence is more susceptible to being rapidly remineralized. We modelled the potential $\mathrm{CO}_{2}$ emissions associated with this disturbance and subsequent remineralization of sediment $\mathrm{C}$ stocks using equation (1) based on varying proportions of sediment $\mathrm{C}$ being exposed to oxic conditions following disturbance:

$$
C(t)=\alpha \times C_{(0)} \times \mathrm{e}^{-k_{1} \times t}
$$

where $C_{(0)}$ is the measured C stock in the top metre, $\alpha$ is the fraction of the $\mathrm{C}$ stock exposed to oxic conditions and $k_{1}$ is the decomposition rate of seagrass sediment $\mathrm{C}$ $\left(0.183 \mathrm{yr}^{-1}\right)^{20}$ in oxic sediment conditions. 
This required a number of assumptions: the $\mathrm{C}$ stock over the top metre $\left(\mathrm{MgCha}^{-1}\right)$ of sampled seagrass meadows was representative of the $\mathrm{C}$ stock contained in sediments within the damaged seagrass area prior to the heatwave; the fraction of the sediment $\mathrm{C}$ in disturbed seagrass meadows exposed to oxic environments was in the range of 0.1 to 0.5 ; the potential contribution of seagrass biomass remineralization to $\mathrm{CO}_{2}$ emissions was not accounted for due to the lack of knowledge about the export and fate of plant biomass following the loss of meadows; and there will be no recovery of seagrass in the long term (that is, $40 \mathrm{yr}$ ). With the exception of the last assumption, these were conservative, in an effort to avoid overestimation of potential $\mathrm{CO}_{2}$ emissions. We assessed the loss of $\mathrm{C}$ to the atmosphere after 3 years post disturbance (in 2014) and also assessed potential releases over a 40 -year time frame consistent with tier 1 and 2 methods of the Intergovernmental Panel on Climate Change (2006) for organic soils. The C stock loss per hectare at 3 years and 40 years post disturbance was multiplied by the damaged seagrass area $\left(1,125 \mathrm{~km}^{2}\right)$.

Data availability. Seagrass sediment data on dry bulk density, $C, \delta^{13} \mathrm{C},{ }^{210} \mathrm{~Pb}$ concentrations and ${ }^{14} \mathrm{C}$ raw ages that support the findings of this study have been deposited in the Edith Cowan University Research portal with the identifier https://doi.org/10.4225/75/5a1640e851af1.

\section{References}

51. Fourqurean, J. W., Kendrick, G. A., Collins, L. S., Chambers, R. M. \& Vanderklift, M. A. Carbon, nitrogen and phosphorus storage in subtropical seagrass meadows: Examples from Florida Bay and Shark Bay. Mar. Freshw. Res 63, 967-983 (2012).

52. Glew, J. R., Smol, J. P. \& Last, W. M. in Tracking Environmental Change Using Lake Sediments: Basin Analysis, Coring, and Chronological Techniques (eds Last, W. M. \& Smol, J. P.) 73-105 (Springer Netherlands, Dordrecht, 2001).
53. Phillips, S. C., Johnson, J. E., Miranda, E. \& Disenhof, C. Improving CHN measurements in carbonate-rich marine sediments. Limnol. Oceanogr. Methods 9, 194-203 (2011).

54. Brodie, C. R. et al. Evidence for bias in $\mathrm{C}$ and $\mathrm{N}$ concentrations and $\delta^{13} \mathrm{C}$ composition of terrestrial and aquatic organic materials due to pre-analysis acid preparation methods. Chem. Geol. 282, 67-83 (2011).

55. Phillips, D. L. \& Gregg, J. W. Source partitioning using stable isotopes: Coping with too many sources. Oecologia 136, 261-269 (2003).

56. Wentworth, C. A scale of grade and class terms for clastic sediments. J. Geol. 30, 377-392 (1922).

57. Flemming, B. W. A revised textural classification of gravel-free muddy sediments on the basis of ternary diagrams. Cont. Shelf Res. 20, 1125-1137 (2000).

58. Sanchez-Cabeza, J. A., Masqué, P. \& Ani-Ragolta, I. ${ }^{210} \mathrm{~Pb}$ and ${ }^{210} \mathrm{Po}$ analysis in sediments and soils by microwave acid digestion. J. Radioanal. Nucl. Chem. 227, 19-22 (1998).

59. Masqué, P., Sanchez-Cabeza, J. \& Bruach, J. Balance and residence times of ${ }^{210} \mathrm{~Pb}$ and ${ }^{210} \mathrm{Po}$ in surface waters of the northwestern Mediterranean Sea. Cont. Shelf Res. 22, 2127-2146 (2002).

60. Krishnaswamy, S., Lal, D., Martin, J. M. \& Meybeck, M. Geochronology of lake sediments. Earth Planet. Sci. Lett. 11, 407-414 (1971).

61. Stuiver, M. \& Polach, H. A. Discussion reporting of ${ }^{14} \mathrm{C}$ data. Radiocarbon 19, 355-363 (1977).

62. Blaauw, M. \& Christen, J. Flexible paleoclimate age-depth models using an autoregressive gamma process. Bayesian Anal. 6, 457-474 (2011).

63. Squire, P. et al. A marine reservoir correction for the Houtman-Abrolhos archipelago, East Indian Ocean, Western Australia. Radiocarbon 55, 103-114 (2013).

64. Webster, R. \& Oliver, M. A. Geostatistics for environmental scientists (Statistics in Practice) (John Wiley \& Sons, Chichester, UK, 2001).

65. Wackernagel, H. Multivariate Geostatistics: An Introduction with Applications (Springer, New York, USA, 2003). 